\title{
URBAN HYDROLOGICAL RESPONSE UNIT PARAMETER CALIBRATION AND VERIFICATION FOR CONCEPTUAL HYDROLOGICAL MODEL METQ
}

\author{
Inga Grinfelde ${ }^{1}$, Anda Bakute ${ }^{2}$ \\ ${ }^{1}$ Latvia University of Agriculture; ${ }^{2}$ Expertisecentrum Regelgeving Bouw, Netherland \\ Inga.grinfelde@1lu.lv
}

\begin{abstract}
The growing urbanization level significantly impacts the hydrological regime of streams and rivers. Land use is changed and natural areas are transformed to living areas or industrial parks. The conceptual hydrological model METQ is developed by the Latvia University of Agriculture to calculate total run-off for different purposes. However, it was developed for rural areas and is missing the urban hydrological response unit. The aim of this research is to calibrate and verify the urban hydrological response unit parameters of the conceptual hydrological model METQ. In Latvia, there is no hydrometric station with urban catchment area and in Europe there was not possibility to get enough long run-off and meteorological data set. Free access run-off and meteorological data from the United States Geological Surveywere used in this research. The calibration was made using MonteCarlo simulations. To evaluate the calibration results Nash-Sutcliffe efficiency index (NSE), determination coefficient $R^{2}$, percent bias (PBIAS), ratios the root mean square error to the standard deviation of measured data (RSR) in addition to the graphical method were used. The calibration and validation results of the urban hydrological response unit parameters were satisfactory and achieved the recommended limits NSE $>0.5$; R2 $>0.75 ;$ RSR $<0.70$ and PBIAS $+/-25 \%$ for all six catchments. There is variation of the parameter values between catchments, which is related with the urbanization level and hydrogeological conditions of the catchment. This paper gives recommendations for hydrological response unit parameter application for the conceptual hydrological model METQUL2012.
\end{abstract}

Keywords: urbanization, discharge, METQUL2012.

\section{Introduction}

More than half of the world population live on urban areas and according to the United Nations migration projections in 2030 more than $80 \%$ of the population will live in urban areas [1]. Growing population and increasing urbanization rate force more and more to think about sustainable resource management, including water management $[2 ; 3]$. The change of land use and especially urbanization have significant impact on hydrological processes [4]. Urban areas, on the one hand, increase pollution pressure and deplete water resources, on the other hand, increase the amount and quality of water supply and sewerage infrastructure, as well as develop a flood protection system [5; 6]. Heavy rainfall in urban areas causes local flooding, which is becoming more and more intensive and repeats more and more often [7-10]. In flood events the most vulnerable social groups of societies suffer, as well as material losses during the flood events each year are several billions $[11 ; 12]$. The European Union flood risk mitigation measures are regulated by the Flood Directive (2007/60/EC), which entails an obligation to the Member States to organize a flood risk assessment and risk areas mapping [13]. At the scientific level, the understanding of the urban area hydrological regime is currently being designed and developed using monitoring data and modeling of the opportunities offered, but there is a need for a longer monitoring period at least two decades, during which to accumulate data of hydrological regimes in urban areas [14-17]. Modelling of urban catchment hydrological regime is difficult because of the fragmented environment with specific hydrological response, and so far, there is no clear understanding of the rain circulation cycles of the urban environment [18]. Bach et al.[19] highlighted the need to classify urban watershed integrated models and recommended to develop the model classification according to the degree of integration. However, there are ongoing discussions about the universal concept of the water cycle at watershed level and development of common methodology.

In Latvia, there was developed a conceptual hydrological model METQ [21; 22] with very good precision. Previous versions of models were developed for natural areas[22]. However, by growing urbanization of natural areas there is a need to integrate this hydrological response unit in hydrological models. The previous experience of integration of the hydrological response unit in the existing conceptual hydrological models shows good results [22-24]. Many researchers prefer manual calibration to increase the model performance [25-29]. The newest version of the METQ model is METQUL2012 where friendly interface and separated hydrological response units calculation modules are used [30].The aim of this research is to calibrate and validate the urban hydrological 
response unit parameters of the conceptual hydrological model METQUL2012 and to give recommendations of the parameter integration in the model.

\section{Materials and Methods}

In Latvia, there are no data of discharge from the urban catchment areas. In the Northern part of Europe there was not a possibility to get enough long run-off and meteorological data set. In this research free access run-off and meteorological data from the United States Geological Survey (USGS) were used. Catchments with area from 9.76 till $183.63 \mathrm{~km}^{2}$ from the cold climate zone where chosen. The location of the urban catchments is presented in Table 1. The smallest catchment is Valley Stream in New York City $9.76 \mathrm{~km}^{2}$ and the largest catchment is Paint Creek in Detroit $183.63 \mathrm{~km}^{2}$. The highest density of waterproof areas is in Valley Stream $95 \%$ and Ecorse River $92 \%$.

Table 1

Characteristics of urban catchments

\begin{tabular}{|c|c|c|c|c|c|c|c|}
\hline $\begin{array}{c}\text { USGS } \\
\text { Number }\end{array}$ & $\begin{array}{c}\text { US } \\
\text { State }\end{array}$ & Name & Latitude & Longitude & $\begin{array}{c}\text { Density of } \\
\text { waterproof } \\
\text { areas, } \%\end{array}$ & $\begin{array}{c}\text { Drainage } \\
\text { area, km }\end{array}$ & Shortening \\
\hline 01302020 & NY & BRONX RIVER & $40^{\circ} 51^{\prime} 44^{\prime \prime}$ & $73^{\circ} 52^{\prime} 27^{\prime \prime}$ & $74 \%$ & 99.45 & NY_BO \\
\hline 01311500 & NY & $\begin{array}{c}\text { VALLEY } \\
\text { STREAM }\end{array}$ & $40^{\circ} 39^{\prime} 49^{\prime \prime}$ & $73^{\circ} 42^{\prime} 16^{\prime \prime}$ & $95 \%$ & 9.76 & NY_VA \\
\hline 04168580 & MI & ECORSE RIVER & $42^{\circ} 16^{\prime} 10^{\prime \prime}$ & $83^{\circ} 17^{\prime} 23^{\prime \prime}$ & $92 \%$ & 25.90 & MI_EC \\
\hline 04161540 & MI & PAINT CREEK & $42^{\circ} 41^{\prime} 18^{\prime \prime}$ & $83^{\circ} 08^{\prime} 35^{\prime \prime}$ & $56 \%$ & 183.63 & MI_PA \\
\hline 12113346 & WA & $\begin{array}{c}\text { SPRINGBROOK } \\
\text { CREEK }\end{array}$ & $47^{\circ} 25^{\prime} 53^{\prime \prime}$ & $122^{\circ} 13^{\prime} 35^{\prime \prime}$ & $71 \%$ & 21.86 & WA_SP \\
\hline 12113349 & WA & MILL CREEK & $47^{\circ} 25^{\prime} 49^{\prime \prime}$ & $122^{\circ} 14^{\prime} 31^{\prime \prime}$ & $86 \%$ & 14.58 & WA_MI \\
\hline
\end{tabular}

Climate of calibration and validation period of urban catchments

Table 2

\begin{tabular}{|c|c|c|c|c|c|c|c|c|c|}
\hline \multirow{2}{*}{ Station } & \multirow{2}{*}{ Parameters } & \multicolumn{4}{|c|}{ Calibration period } & \multicolumn{4}{|c|}{ Validation period } \\
\hline & & 2008 & 2009 & 2010 & 2011 & 2012 & 2013 & 2014 & 2015 \\
\hline NY_BO & \multirow{6}{*}{$\begin{array}{c}\text { Annual average } \\
\text { temperature, } \\
{ }^{\circ} \mathrm{C}\end{array}$} & 11.1 & 10.7 & 11.9 & 11.9 & 12.7 & 11.4 & 10.7 & 11.4 \\
\hline NY_VA & & 11.1 & 10.7 & 11.9 & 11.2 & 12.6 & 11.3 & 10.7 & 11.4 \\
\hline WA_SP & & 9.2 & 9.8 & 10.4 & 9.3 & 10.0 & 10.1 & 10.9 & 11.5 \\
\hline WA_MI & & 9.2 & 9.8 & 10.4 & 9.3 & 10.0 & 10.1 & 10.9 & 11.5 \\
\hline MI_EC & & 8.3 & 8.1 & 9.5 & 9.0 & 10.5 & 8.2 & 6.9 & 9.0 \\
\hline MI_PA & & 8.3 & 8.1 & 9.5 & 9.0 & 10.5 & 8.2 & 6.9 & 9.0 \\
\hline NY_BO & \multirow{6}{*}{$\begin{array}{c}\text { Annual sum of } \\
\text { precipitation, } \\
\text { mm }\end{array}$} & 1382.2 & 1402.0 & 1068.3 & 1143.9 & 1104.3 & 1044.2 & 1224.7 & 899.3 \\
\hline NY_VA & & 1382.2 & 1402.0 & 1068.3 & 1143.9 & 1104.3 & 1044.2 & 1224.7 & 899.3 \\
\hline WA_SP & & 653.4 & 1228.6 & 1800.6 & 1327.1 & 1785.8 & 704.8 & 1435.5 & 1230.0 \\
\hline WA_MI & & 653.4 & 1228.6 & 1800,6 & 1327.1 & 1785.8 & 704.8 & 1435.5 & 1230.0 \\
\hline MI_EC & & 720.0 & 714.9 & 635.4 & 1085.0 & 527.3 & 1318.8 & 712.4 & 569.1 \\
\hline MI_PA & & \begin{tabular}{|l|}
720.0 \\
\end{tabular} & 714.9 & 635.4 & 1085.0 & 527.3 & 1318.8 & 712.4 & 569.1 \\
\hline NY_BO & \multirow{6}{*}{$\begin{array}{c}\text { Annual } \\
\text { minimal run- } \\
\text { off, } \mathbf{m}^{3} \cdot \mathbf{s}^{-1}\end{array}$} & 0.566 & 0.510 & 0.340 & 0.481 & 0.340 & 0.280 & 0.397 & \begin{tabular}{|l|}
0.340 \\
\end{tabular} \\
\hline NY_VA & & 0.000 & 0.000 & 0.000 & 0.000 & 0.000 & 0.002 & 0.003 & 0.000 \\
\hline WA_SP & & 0.034 & 0.054 & 0.082 & 0.099 & 0.127 & 0.108 & 0.110 & 0.014 \\
\hline WA_MI & & 0.006 & 0.016 & 0.024 & 0.040 & 0.025 & 0.037 & 0.028 & 0.000 \\
\hline MI_EC & & \begin{tabular}{|l|l|}
0.005 \\
\end{tabular} & 0.011 & 0.018 & 0.014 & 0.007 & 0.014 & 0.010 & \begin{tabular}{|l|}
0.012 \\
\end{tabular} \\
\hline MI_PA & & 0.425 & 0.538 & 0.283 & 0.397 & 0.249 & 0.397 & 0.623 & 0.368 \\
\hline NY_BO & \multirow{6}{*}{$\begin{array}{c}\text { Annual } \\
\text { maximal run- } \\
\text { off, } \mathrm{m}^{3} \cdot \mathrm{s}^{-1}\end{array}$} & 21.637 & 23.562 & 31.718 & 62.587 & 13.650 & 26.054 & 30.302 & 18.068 \\
\hline NY_VA & & \begin{tabular}{|l|}
1.529 \\
\end{tabular} & 1.218 & 2.322 & 3.257 & 0.595 & 1.359 & 2.322 & 0.736 \\
\hline WA_SP & & 3.030 & 3.285 & 4.191 & 2.605 & 2.209 & 3.993 & 1.926 & 3.257 \\
\hline WA_MI & & \begin{tabular}{|l|}
3.767 \\
\end{tabular} & 4.475 & 4.843 & 3.512 & 3.144 & 4.050 & 3.597 & \begin{tabular}{|l|}
4.729 \\
\end{tabular} \\
\hline MI_EC & & 5.296 & 4.588 & 7.335 & 6.542 & 3.342 & 3.852 & 7.477 & 3.653 \\
\hline MI_PA & & 16.709 & 12.433 & 7.307 & 11.328 & 7.392 & 15.859 & 10.563 & \begin{tabular}{|l|}
7.816 \\
\end{tabular} \\
\hline
\end{tabular}


The air temperature, precipitation and humidity data were used from the closest meteorological station in USGS data base.The air temperature, precipitation and humidity of calibration and validation periods are presented in Table 2 . All six catchments represent cold climate with different continentality. The annual average air temperature is higher in New York City (NY_BO and NY_VA) and lower in Detroit (MI_EC and MI_PA). The annual precipitation varies from 527.3 in Detroit to 1785.8 (MI_EC and MI_PA) mm in Seattle (WA_SP and WA_MI).The calibration of the parameters of the urban hydrological response unit was made according to the flowchart presented in Figure 1.

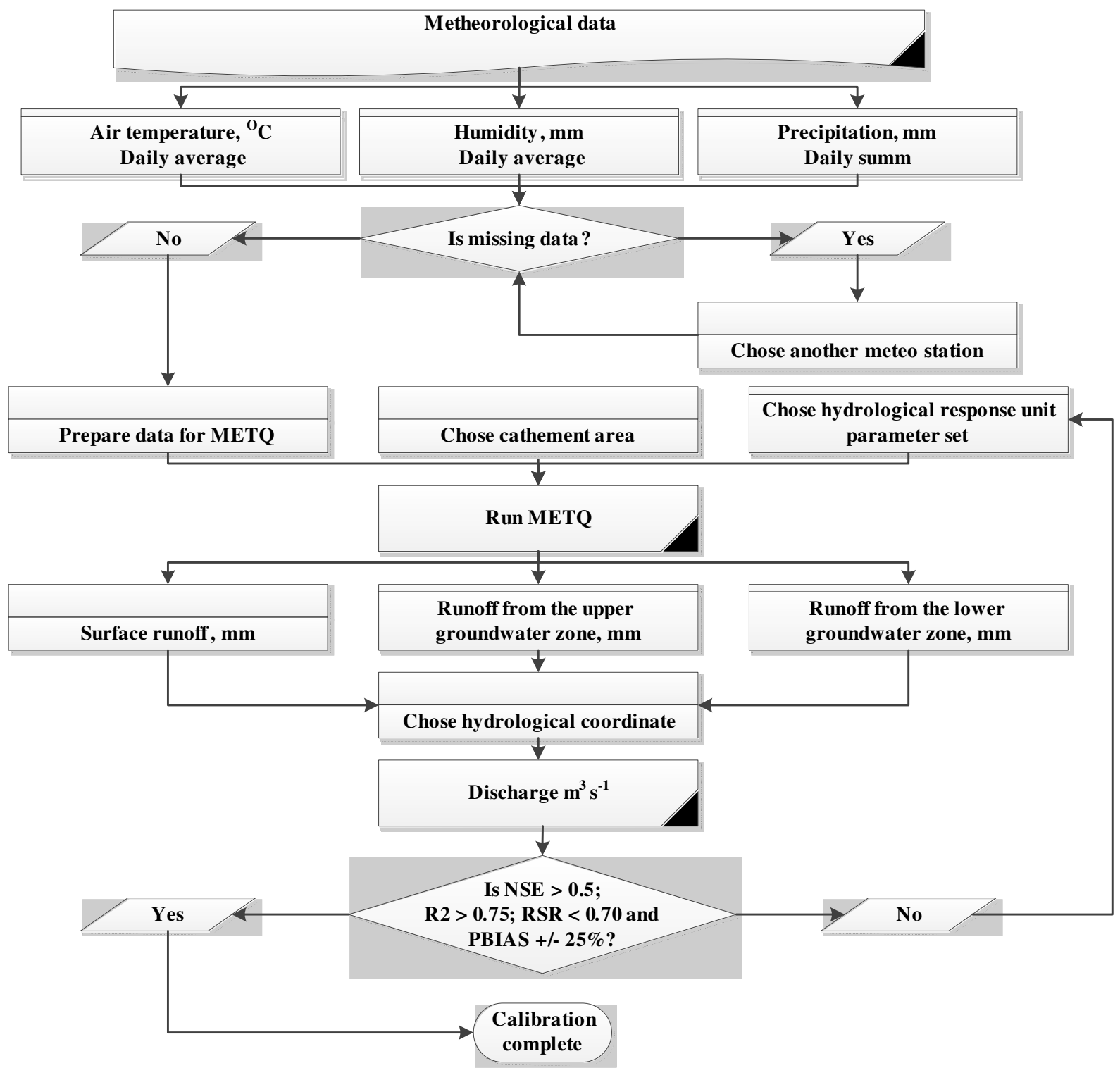

Fig. 1. Flowchart of urban hydrological response unit calibration steps

The conceptual hydrological model METQUL2012 calculates discharge of each hydrological response unit using the daily temperature, precipitation and humidity data. The calculation algorithm consists of 23parameters: WMAX; ALPHA; ZCAP; A2; A3; KU; KL; CMELT; T1; T2; KS; DZ; PZ; RROB; RROBZ; RROB2; RROBZ2; ROBK; WHC; CFR; DPREC; AMCOR; BETA[20;21].The model METQUL2012 does not accept missing data, the meteorological data from the United States Geological Survey (USGS) were tested for the missing values. The Meteorological data set was uploaded in the model. All catchments are in urban areas, this means the catchment area is the urban hydrological response unit area. The hydrological response unit parameters were calibrated using MonteCarlo simulations and manual calibration of the parameters. To evaluate the calibration results the Nash-Sutcliffe efficiency index (NSE) [31], which is commonly used in hydrology, determination coefficient $R^{2}[32]$, percent bias (PBIAS) [33], ratios the root mean square error to the standard 
deviation of the measured data (RSR) [34] in addition to the graphical method were used. The recommended limits by Moriasi [35] is NSE $>0.5$; R2 $>0.75$; RSR $<0.70$ and PBIAS +/- $25 \%$.

\section{Results and Discussion}

For all catchments, totally 30240 simulations of discharge were done. The best calibration results and verification results are presented in Table 3. The Nash-Sutcliffe efficiency index (NSE) is acceptable [35] and varies from 0.69 to 0.96 for the calibration period and from 0.67 to 0.91 for the validation period. The $\mathrm{R}^{2}$ is acceptable for all catchments for all periods [35] and varies from 0.81 to 0.98 for the calibration period and from 0.79 to 0.95 for the validation period.

Table 3

Results of calibration of model METQUL2012

\begin{tabular}{|c|c|c|c|c|c|c|c|c|}
\hline \multirow{2}{*}{ Catchment } & \multicolumn{4}{|c|}{ Calibration period } & \multicolumn{4}{c|}{ Validation period } \\
\cline { 2 - 9 } & NSE & R2 & RSR & PBIAS & NSE & R2 & RSR & PBIAS \\
\hline NY_BO & 0.69 & 0.81 & 0.69 & -23.63 & 0.67 & 0.79 & 0.70 & -24.87 \\
\hline NY_VA & 0.78 & 0.91 & 0.47 & 11.67 & 0.79 & 0.91 & 0.44 & 10.18 \\
\hline WA_SP & 0.82 & 0.93 & 0.31 & -3.03 & 0.80 & 0.92 & 0.30 & -3.48 \\
\hline WA_MI & 0.96 & 0.98 & 0.21 & -1.07 & 0.91 & 0.95 & 0.24 & -2.11 \\
\hline MI_EC & 0.76 & 0.87 & 0.43 & 14.86 & 0.73 & 0.84 & 0.49 & 16.36 \\
\hline MI_PA & 0.72 & 0.84 & 0.40 & 17.01 & 0.75 & 0.87 & 0.42 & 15.28 \\
\hline
\end{tabular}

The NY_BO shows better modelling results at the calibration period, however, MI_PA shows to be better fit for the validation period than for the calibration period. Several factors influence the model fit: the precision of the precipitation data; the discharge measurement precision and the conditions of the riverbed.

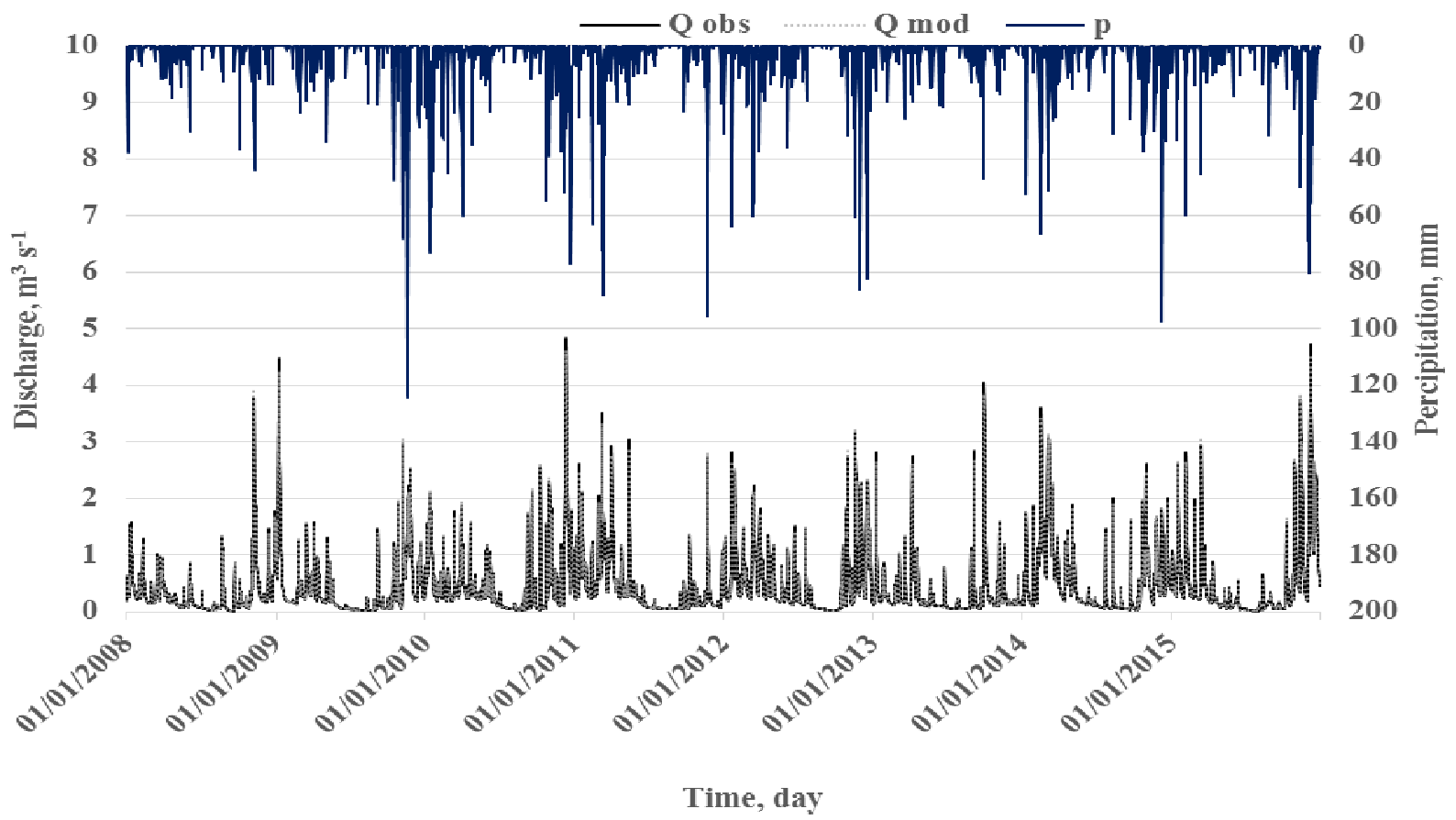

Fig. 2. Modelled and observed discharge and percipitation of WA_MI cathement

The conceptual hydrological model METQ parameters (A2; A3; CMELT; DZ; PZ; RROB; RROBZ; RROB2; RROBZ2; ROBK; DPREC; AMCOR; BETA) can be calibrated for rural catchments [21] and other parameters are constant. During calibration of the urban hydrological response unit parameters there was made a decision to calibrate additional parameters (WMAX; ALPHA; ZCAP; KU; KL; T1; T2; KS; WHC; CFR; AMCOR). In urban areas, there is high heterogeneity of the surface and disturbed stream formation as well as different microclimate [36]. The best fit of the modelled and observed discharge is presented in Figure 2. The modelled and 
observed discharges show good fit, however there are underestimation or overestimation of discharge. This uncertainty is related with measurement precision and rain event distribution in the catchment area.The parameters WMAX, ALPHA, ZCAP, T1, T2, KS, DZ, PZ, DPREC, BETA show significant variance - larger than $20 \%$ between the catchments and in some cases more than $40 \%$. The variation is related with heterogeneity of the land cover, historical development of the storm water collection system and urbanization density [36]. There is a need to classify urban catchments by covered areas and develop at least three urban hydrological response unit parameter sets and integrate the calculation algorithm in the conceptual hydrological model METQUL 2012.

\section{Conclusions}

1. The calibration and validation results of the urban hydrological response unit parameters weresatisfactory and achieved the recommended limits NSE $>0.5 ; \mathrm{R} 2>0.75 ; \mathrm{RSR}<0.70$ and PBIAS +/- $25 \%$ for all six catchments.

2. There is variation of the parameter values between the catchments, which is related to the urbanization level and hydrogeological conditions of the catchment.

3. It is recommended to classify urban catchments by covered areas and develop at least three urban hydrological response unit parameter sets and integrate additional calculation algorithms in the conceptual hydrological model METQUL 2012.

\section{References}

1. United Nations, Department of Economic and Social Affairs, Population Division (2015). World Population Prospects: The 2015 Revision, Key Findings and Advance Tables. Working Paper No. ESA/P/WP.241

2. Lee J.G. Heaney, J.P. Estimation of urban imperviousness and its impacts on storm water systems. J. Water Res. Plan. ASCE vol.129 (5), 2003, pp. 419-426.

3. Carle, M.V., Halpin, P.N., Stow, C.A. Patterns of watershed urbanization and impacts on water quality. J. Am. Water Resour. Assoc. vol. 41 (3), 2005, pp. 693-708.

4. DeFries R., Eshleman N.K. Land-use change and hydrologic processes: a major focus of the future. Hydrol. Process. vol.18 (11), 2004, 2183-2186.

5. Vizintin G., Souvent P., Veselic M., Curk C. Determination of urban groundwater pollution in alluvial aquifer using linked process models considering urban water cycle. J. Hydrol. Vol. 377 (3-4), 2009, pp. 261-273.

6. Carey R.O., Hochmuth G.J., Martinez D.J., Boyer T.H., Dukes M.D., Toor G.S., Cisar J.L. Evaluating nutrient impacts in urban watersheds: challenges and research opportunities. Environ. Pollut. Vol. 173, 2013, 138-149.

7. Kang I.S., Park J.I., Singh V.P. Effect of urbanization on runoff characteristics of the On-Cheon stream watershed in Pusan, Korea. Hydrol. Process. vol. 12 (2), 1998, pp. 351-363.

8. Mark O., Weesakul S., Apirumanekul C., Aroonnet S.B., Djordjevic' S. Potential and limitations of 1D modelling of urban flooding. J. Hydrol. Vol. 299 (34), 2004, pp. 284-299.

9. Schmitt T.G., Thomas M., Ettrich N. Analysis and modeling of flooding in urban drainage systems. J. Hydrol. Vol. 299 (3-4), 2004, pp. 300-311.

10. Chen J., Arleen A.H., Lensyl D.U. A GIS-based model for flood inundation. J. Hydrol. Vol. 373 (1-2), 2009, pp. 184-192.

11. Jonkman S.N., Vrijling J.K. Loss of life due to floods. J. Flood Risk Manage. Vol. 1 (1), 2008, pp. 43-56.

12. Kron W., Steuer M., Löw P., Wirtz A. How to deal properly with a natural catastrophe database analysis of flood losses. Nat. Hazards Earth Sys. Vol.12 (3), 2012, pp. 535-550.

13. CEC, 2007. Directive Concerning EU Floods. 2007/60/EEC. CEC, Luxemburg.

14. Delleur J.W. The evolution of urban hydrology: past, present, future. J. Hydraul. Eng. ASCE vol. 129 (8), 2003, pp. 563-573.

15. DeFries R., Eshleman N.K. Land-use change and hydrologic processes: a major focus of the future. Hydrol. Process. vol. 18 (11), 2004, pp. 2183-2186.

16. Praskievicz S., Chang, H. A review of hydrological modelling of basin-scale climate change and urban development impacts. Prog. Phys. Geog. Vol. 33 (5), 2009, pp. 650-671. 
17. Fletcher T.D., Andrieu H., Hamel P. Understanding, management and modelling of urban hydrology and its consequences for receiving waters: a state of the art. Adv. Water Resour. Vol. 51, 2013, pp. 261-279.

18. Rodriguez F., Andrieu H., Zech Y. Evaluation of a distributed model for urban catchments using a 7-years continuous data series. Hydrol. Process. vol. 14 (5), 2000, pp. 899-914.

19. Bach, P.M., Rauch, W., Mikkelsen, P.S., McCarty, D.T., Deletic, A. A critical review of integrated urban water modelling - urban drainage and beyond. Environ. Modell. Softw. 54, 2014, pp. 88-107.

20. Ziverts A., Krams M. Experiments of Conceptual Mathematical Groundwater Dynamics and Runoff Modelling in Latvia. Nordic Hydrology, Vol. 24,1993, pp. 243-262.

21. Ziverts A., Jauja I. Mathematical model of hydrological processes METQ98 and its applications. Nordic Hydrologyvol. 30 , 1999, pp. 109-128.

22. Singh R., Maheshwari B., Malano, H.M. Developing a Conceptual Model for Water Accounting in Peri-urban Catchments. Cairns, Australia, vol. 29, 2009, pp. 3654-3660.

23. Te Linde A.H., Aerts J.C.J.H., Kwadijk J.C.J. Effectiveness of flood management measures on peak discharges in the Rhine basin under climate change. J. Flood Risk Manage. Vol. 3 (4), 2010, pp. 248-269.

24. Brun S.E., Band L.E. Simulating runoff behavior in an urbanizing watershed. Comput. Environ. Urban Syst. vol. 24 (1), 2000, pp. 5-22.

25. Vrebos D., Vansteenkiste T., Staes J., Willems P., Meire P. Water displacement by sewer infrastructure in the Grote Nete catchment, Belgium, and its hydrological regime effects. Hydrol. Earth Syst. Sci. vol.18 (3), 2014, pp. 1119-1136.

26. Pan A., Hou A., Tian F., Ni G., Hu H. Hydrologically enhanced distributed urban drainage model and its application in Beijing city. J. Hydrol. Eng. Vol. 17 (6), 2012, 667-678.

27. Ogden F.L., Pradhan N.R., Downer C.W., Zahner J.A. Relative importance of impervious area, drainage density, width function, and subsurface storm drainage on flood runoff from an urbanized catchment. Water Resour. Res. Vol. 47 (12), 2011, W12503.

28. Morris B., Rueedi J., Cronin A.A., Diaper C., DeSilva D. Using linked process models to improve urban groundwater management: an example from Doncaster England. Water Environ. J. vol. 21 (4), 2007, pp. 229-240.

29. Aronica G., Cannarozzo M. Studying the hydrological response of urban catchments using a semi-distributed linear non-linear model. J. Hydrol. Vol. 238 (1-2), 2000, pp. 35-43.

30. Grinfelde I., Lauva D., Autocalibration feasibility and urbanization dimension integration in regional model METQ. Conference Proceedings HydroPredict2012, Predictions for Hydrology, Ecology and Water Resources Management: Water Resources and Changing Global Environment, edited by Peter Nachtnebel \& Karel Kovar, 2012, pp. 61.

31. Nash J.E., Sutcliffe J.V.. River flow forecasting through conceptual models: Part 1. A discussion of principles. J. Hydrology vol. 10(3),1970, pp. 282-290.

32. Legate, D. R., McCabe G. J.. Evaluating the use of "goodness-of-fit" measures in hydrologic and hydroclimatic model validation. Water Resources Res. Vol. 35(1),1999, pp. 233-241.

33. Gupta H.V., Sorooshian S., Yapo P.O. Status of automatic calibration for hydrologic models: Comparison with multilevel expert calibration. J. Hydrologic Eng. Vol. 4(2): 1999, pp. 135-143.

34. Singh J., Knapp H.V., Arnold J.G., Demissie M. Hydrologic modeling of the Iroquois River watershed using HSPF and SWAT. J. American Water Resources Assoc. vol. 41(2): 2005, pp. 361-375.

35. Moriasi D.N., Arnold J.G., Van Liew M.W., Binger R.L., Hamel R.D., Veith T.L. Model Evaluation Guidelines for Systematic Quantification of Accuracy in Watershed Simulations. American Society of Agricultural and Biological Engineers, Vol. 50(3), 2007, pp. 885-900.

36. Van de Ven, F.H.M. Water Balances of Urban Areas. Hydrological Processes and Water Management in Urban Areas, IAHS Publication vol. 198. 1990, pp. 21-32. 